\title{
eGovernment Initiatives Case Study: New Models for Success
}

\author{
Douglass P. Smith \\ Emporia State University
}

\begin{abstract}
This case study examines the efforts of a mid-tier, cabinet-level state agency to transform its constituency services to be more effective using information technology. The agency, based in a rural Midwestern state, faced increased scrutiny to raise accuracy, lower wait times, decrease expenditures, increase constituency satisfaction, and expand services to the state. To meet these challenges, the agency conducted a series of meetings to determine best possible opportunities for change and decided that technology solutions, which supported their business vision of the future, would be the foundation for that change. Redesigning core organizational processes-using several technologies such as e-commerce, content management system, data warehousing, and mobile technologies-would revolutionize how the agency delivers these services to its constituency. Along the way, agency encountered several challenges such as staff turnover, leadership issues, outsourcing issues, and implementation issues. At the heart of their experience lie four theories: the technology adoption model, task-technology fit model, Delone-McLean model of information systems success, and Leavitt's model of organizational change (or Leavitt's diamond). This case will not only examine the academic issues surrounding the aforementioned theories, but will also discuss how the agency navigated through real-world issues to meet these challenges. By increasing the quality and quantity of information that governmental bodies provide "Joe Citizen," our populations are able to have opportunities to be more self-sufficient and are able to hold our public trust more accountable and responsive to the needs of an evergrowing, ever-changing society at large.
\end{abstract}

Keywords: eGovernment, knowledge management, business process reengineering, information technology

\section{Introduction}

Many governments-local, state, and federal agencies in the United States-are overburdened with the demands of an ever-growing population of diverse and sometimes competing organizational agendas, missions, operational goals, and objectives (Bowman \& Kearney, 2012). With each additional challenge, ongoing informational and transactional systems and services, some which can be critical, are becoming less able to meet the needs or the demands of those constituents who rely on such services (Chhabra, 2009). Each agency is being asked to serve its constituency more effectively with fewer funding opportunities. As the nation as a whole continues to struggle with its economic recovery, these agencies can no longer count on historic levels of funding from year to year. In fact, most agencies can count on budget cuts being the norm rather than the exception. These agencies are moving to information technology (IT) as a vehicle to meet these demands (Janssen, Rotthier, \& Snijkers, 2004). Agency heads, despite the funding issues, recognize that optimized technology can decrease the cost of serving the public need. 
The agency represented in this case study has turned to technology to create superior services for its constituents at a time when its funding wasn't optimal compared to the agency's growing mission. This case study will examine the agency's foray into the e-services environment to gain efficiencies previously considered out of reach. Specially, this case study will examine the culture and environment surrounding the agency. The study will also examine the strategy that the agency has developed to meet the demands of operating and providing services on the Internet. Finally, the case will interpret how this agency handled its challenges through the lens of eGovernment (information and communications technology to improve the activities of public sector organizations; Heeks, 2008) using technology in making its case that its ability to bring more timely and quality services to its constituents paves the way for increased opportunities for social change. With many agencies being asked to do more with less, the lessons learned from this case will prove useful to other agencies that are tasked with similar challenges. The objective of this case study is to affirm the use of eGovernment as a strategic tool to enhance the common good of citizens.

This case study is presented in five distinct areas: (a) the introduction; (b) the literature review, which will focus on eGovernment research in the context of this case; (c) an analysis of four theories (the technology adoption model [TAM], task-technology fit model [TTF], Delone-McLean model of information systems [IS] success, and Leavitt's model of organizational change) may apply to the phenomena of eGovernment initiatives. Further, we will look at which core theory is the most appropriate for eGovernment initiatives; (d) the case background focuses on a specific state-level government agency and its efforts to use IT as a strategic tool for knowledge management (KM) and business process reengineering in 2003, including an e-services plan for the agency using these tools and techniques; (e) the conclusion contains a discussion of future issues to explore within the conceptual framework presented in this case study.

\section{Literature Review: eGovernment}

Within the last few years, the body of knowledge and research on eGovernment has grown. Scholars have focused on several areas of importance: usability, accessibility, and acceptance, as well as assessments as they pertain to the public sector. This brief discussion touches on these points relative to the forthcoming discussion of the case.

\section{Usability and Accessibility}

Technology in the context of eGovernment must be usable to be useful and to promote the well-being of the citizenry (Fountain, 2001). An ever-growing chorus of researchers like Jaeger (2004a, 2004b) and Ward, Baker, and Moon (2009) made the call that in order for eGovernment initiatives to be widely adopted by the public, these initiatives (often web-based) must be accessible to our least technically literate person or our most disabled citizen (Becker, 2005). These writers suggest that just meeting Section 508 of the Americans with Disabilities Act is somewhat disingenuous, as it is barely capable of keeping up with the advancements of technology used on the Internet (Baker, Hanson, \& Myhill, 2009). It is therefore the responsibility of those in the public sector to ensure that accessible standards are not only met but adequately exceeded for the maximum amount of usability across a wide spectrum of individuals.

\section{Acceptance}

By far, there is an abundance of recent literature that concerns itself with recent emergence and adoption of eGovernment solutions. The 2004 edition of the Information Management Journal suggested that most citizens prefer to deal with the government via telephone, fax, and face to face 
(Swartz, 2004), but as the Internet is gaining popularity as a tool to conduct business, the pendulum of contact preference is turning. Qureshi (2005) noted in his article that while the use of the web is increasing, we are seeing the proliferation of applications that can be used via mobile phones. A 2010 report by the Pew Research Center suggested over $80 \%$ of Internet users, representing over $60 \%$ of American adults, looked for information or conducted a transaction on a government website (Smith, 2010). Such acceptance and usage is placed, in part, on which tools that the public sector chooses to use. No matter which form of technology used, it is apparent that eGovernment initiatives are here to stay and proliferating at an increasing pace.

\section{Issues for Implementation and Operations}

As public dollars and trust are being placed into these projects, useful assessments are necessary to judge the efficacy of any wide-reaching system in days where there are readily available examples of large public sector dollars being misspent on antiquated technology. Kunstelj and Vintar (2004) put forth a position that many eGovernment projects fall short of their more far-reaching goals, by settling for lower tier integrative layers of technology solutions (e.g., brochure websites).

Additionally, without advancing a holistic approach, typified by projects that integrate transactional processing, with constituency management, along with back-office functions, the promise of eGovernment cannot truly be fulfilled. A holistic approach to eGovernment solutions will not only address the technological and process-oriented issues, but it will also account for changes in population (e.g., Baby Boomers vs. Millennials). While resources to fund these solutions remain scarce, there are methods and models that could place agencies on a path that would account for most of the challenges presented (Kunstelj \& Vintar 2004):

1. Total absence - There is an absence of any publicly accessible website managed by the service provider.

2. Information - The information necessary to start the procedure to obtain this service is available online.

3. One-way interaction - The publicly accessible website offers the possibility to obtain (via download) the paper form to start the procedure to obtain this service; an electronic form to order a nonelectronic form is also considered at this stage.

4. Two-way interaction - The publicly accessible website offers the possibility of an electronic intake with an official electronic form to start the procedure to obtain this service; this implies that there must be a form of authentication of the person (physical or juridical) requesting the service in order to reach Stage 3.

5. 100\% Transaction - The publicly accessible website offers the possibility to completely treat the public service via the website, including decision, delivery, and payment, if necessary. No other formal procedure is necessary for the applicant via paperwork.

Any attempt to address problems without a 360-degree or holistic approach to problem solving will potentially overlook a key process area or constituent.

\section{Core Theories Presented in This Case Study}

\section{Technology Adoption Model}

TAM was developed first by Fred Davis, Richard Bagozzi, and Paul Warshaw in 1989 and refined further in 1992 (Bagozzi, Davis, \& Warshaw, 1992; Davis, 1989; Davis, Bagozzi, \& Warshaw, 1989). TAM was an extension of Ajzen and Fishbein's (1980) theory of reasoned action, which states that beliefs influence attitudes, which craft intentions that lead to behaviors. Yet, TAM replaces theory of 
reasoned action's attitude metrics (Budd, 1987) with two technology acceptance measures-ease of use and usefulness.

TAM is useful in this case because as Bagozzi and colleagues (1992) said,

Because new technologies such as personal computers are complex and an element of uncertainty exists in the minds of decision makers with respect to the successful adoption of them, people form attitudes and intentions toward trying to lean to use the new technology prior to initiating efforts directed at using. Attitudes towards usage and intentions to use may be ill-formed or lacking in conviction or else may occur only after preliminary strivings to lean to use the technology evolve. Thus, actual usage may not be a direct or immediate consequence of such attitudes and intentions. (p. 664)

In other words, users adopt complex new technology with skepticism, which can be alleviated by the perceived usefulness and ease of use that the technology offers. In the context of eGovernment initiatives, TAM becomes important in predicting the solution's adoption by staff as well as other agency constituents. This prediction can play an important part in the public sector, where the success of a system is fueled in large part by its adoption and, in turn, can determine cost savings through the use of technology(see Figure 1).

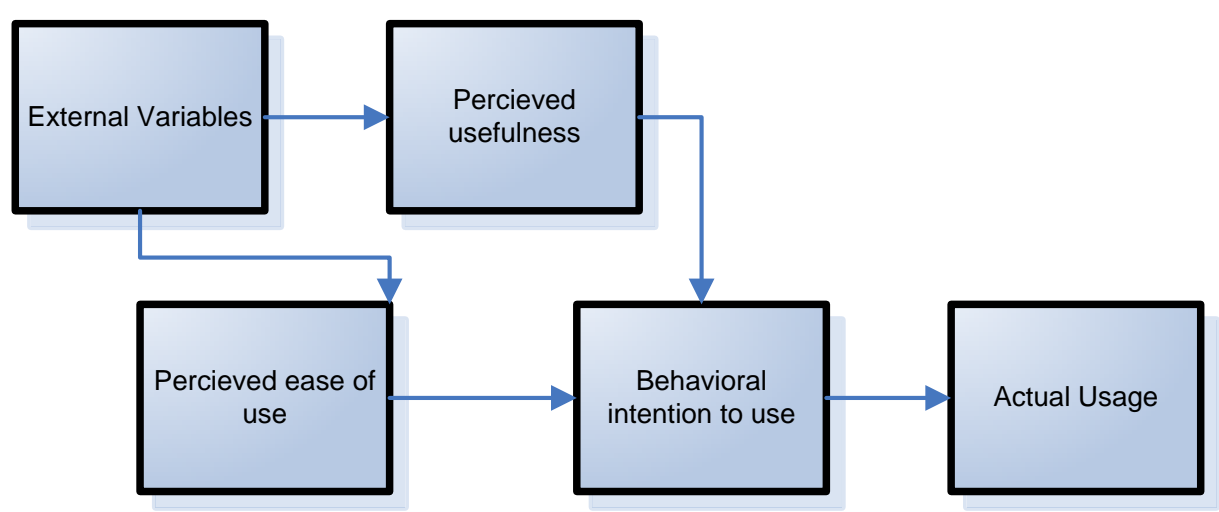

Figure 1: The Technology Adoption Model (Venkatesh \& Davis, 1996)

Even though TAM provides us with one aspect to formulate our theories on eGovernment initiatives, it isn't enough. We must look at other theories to complete the picture.

\section{Task-Technology Fit Model}

TAM represents only part of the dilemma facing eGovernment initiatives. However, when TAM is coupled with TTF, it can provide a more robust structure to engage a discussion. TTF delineates that adoption of technology depends on how well suited the technology is for the task (Goodhue \& Thompson, 1995). Specifically, it allows that technology will be used if its functions support the end user's purpose, while, at the same time, the cost of using the software must be lower than the alternative. In this way, the perception of utility can push forward the notion of intent to use (Stewart, 1986). 
When evaluating technologies, one of the metrics involved is the ability or effectiveness of the technology to task. This is where TTF has a role in technology adoption (Keil, Beranek, \& Konsynski, 1995). The combination of TAM and TTF is particularly effective (Dishaw \& Strong, 1998a, 1998b). A similar construct for eGovernment initiatives can be used (see Figure 2):

1. Many eGovernment initiatives have e-commerce as a subsystem.

2. Both types of projects use the Internet as a user interface and a datatransport mechanism.

3. The success of both largely depends on the ease of use to increase user participation/engagement/usage as a preferred method of interacting with the organization.

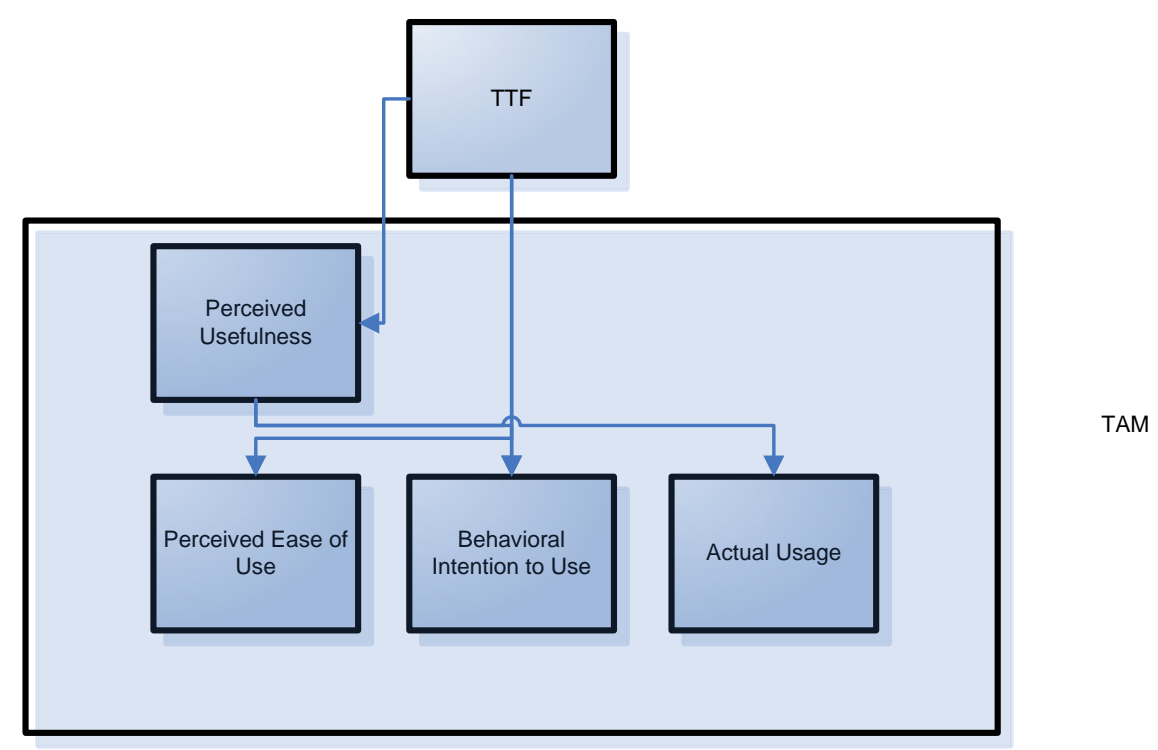

Figure 2: Combined Technology Adoption/Task-Technology Fit Model

This combined model gives us the following outcomes, as stated by Goodhue in 1995:

1. The combined TTF/TAM predicts the intention to use and actual use.

2. TTF is positively related to perceived usefulness.

3. TTF is positively related to perceived ease of use.

4. TTF is positively related to the intention to use online self-service items (bill payment, address changes, reporting generating, etc.).

This combined model has not been tested yet in an eGovernment setting.

\section{Delone-McLean Model of IS Success}

Delone and McLean $(1992,2002)$ wrote what has become a widely used model for predicting the success of an IS project (see Figure 3). An examination of the model shows that similarities with the two theories previously discussed (variables of use, user satisfaction, usefulness, and the intention to use in the prior discussion) have an overall impact on the individual and the organization. This can be extrapolated to determine the success of the project. Yet, this model is a bit different, as it also considers the system quality and information quality. 


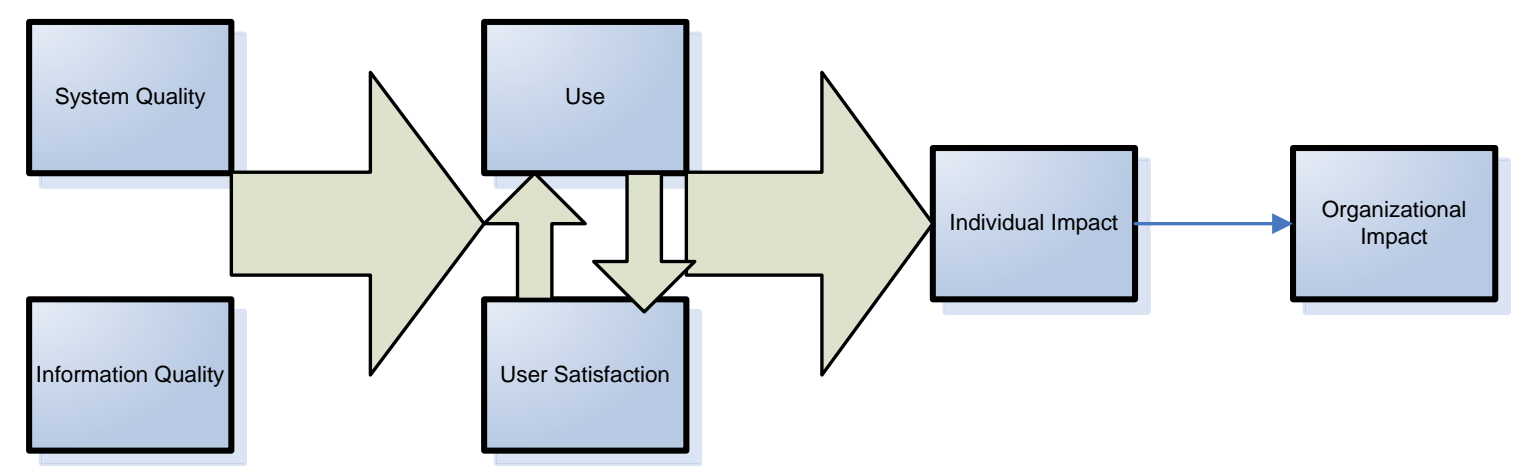

Figure 3: Delone-McLean Model

\section{The Combined Model for eGovernment Projects}

Given the overlap and nonoverlap of these theories, an interesting question arises: Can these three theories be combined, or are they mutually exclusive? While there's no statistical evidence presented in this article to support this combination, this case proposes that a combination of these theories can be applied to eGovernment (see Figure 4).

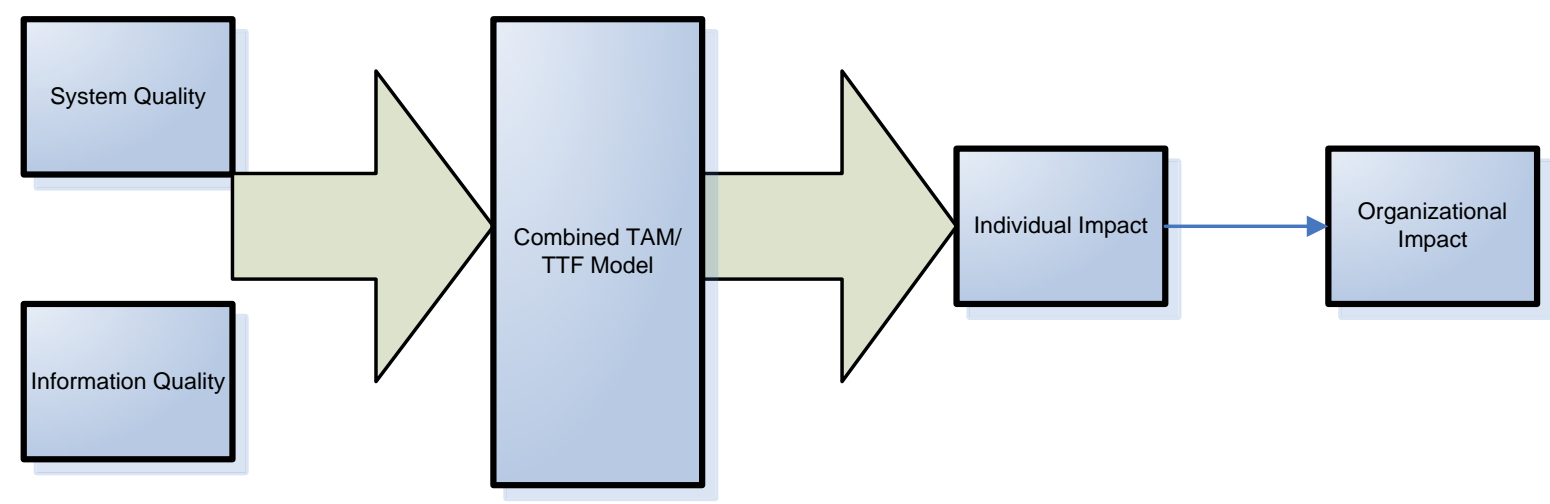

Figure 4: Combined Technology Adoption/Task-Technology Fit/McLean Model

When taken together, the combined model captures and considers

- the quality of the technology,

- the "intentions" of constituents who will use the site,

- the probability that the system will be used by staff, and

- the likelihood that the solution itself will have an impact on the organization.

\section{Leavitt's Model of Organizational Change}

This is the last model of our discussion. While not directly aimed at IT, this case study would be remiss without this discussion, as this model speaks to how this particular project can bring this organization into an era of the KM culture. 


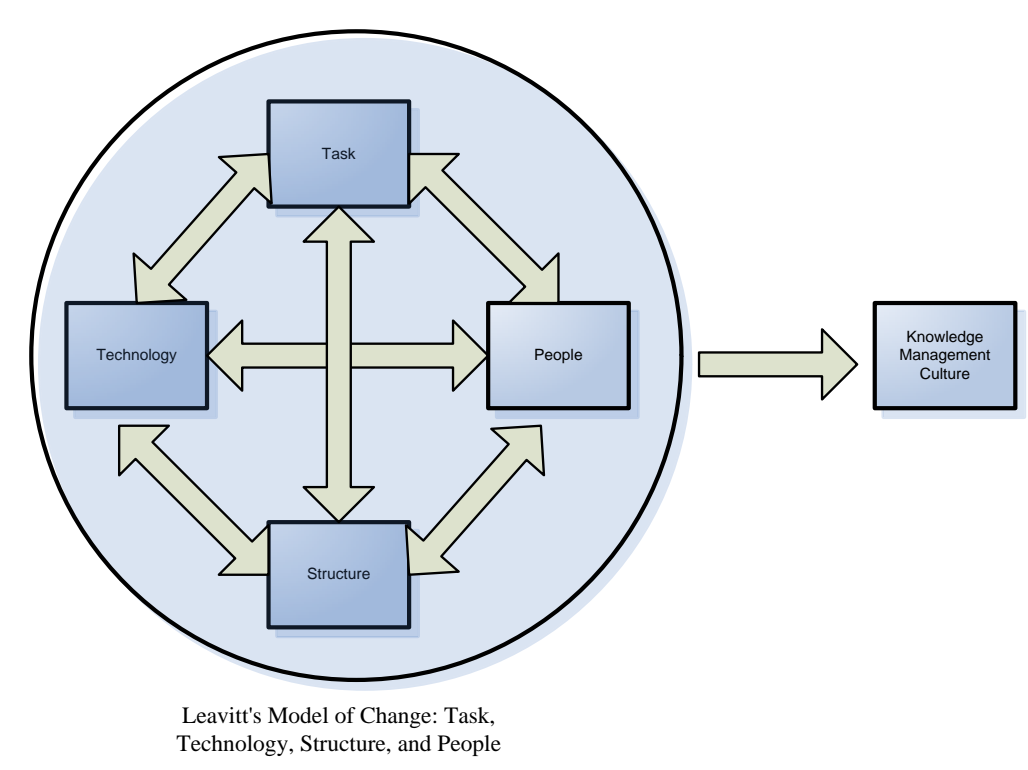

Figure 5: Leavitt's (1965) Model

Within this model, we can notice that each of the four variables interacts with the others (see figure 5). However, for a culture of KM to evolve, these items must be "balanced and coordinated" (Hurley \& Green, 2005).

- Technology - Within the case study, we will see how technology plays a big factor. In this case, technology replaces several antiquated systems and ties several currently disconnected systems into a unified technology.

- Structure - The solution derived restructures a few key areas of the organization into more efficient, productive units.

- People - The structure and the technology force the organization to focus on the people, ensuring that they are properly trained (both internally and externally).

- Tasks - Again, the other three variables all combine to streamline the tasks that will be performed by the staff and that will now be handled automatically by the system.

With this system in mind, we can then use the information and knowledge that is generated by the new solution to empower the organization to do new, more innovative things. With these theories in mind, we turn to the actual case itself. This case showcases these underlying theories.

\section{Case Background: Midwest State Agency}

\section{Organization Background}

For the purposes of this discussion, the agency in question will be referred to as a Midwestern state agency (MSA). The MSA was located in largely a historical agricultural community and played an important role to the citizens and state as the vanguard of the agriculture industry. However, despite the importance of agriculture to the state, the agency maintained only a mid-tier status among the state agencies. This mid-tier status meant, among other issues, that funding and resource scarcity were paramount issues each year. As of 2003, the agency's annual budget hovered around $\$ 15$ million, in a mix of general state funding dollars and program-specific fee funding. The agency 
had about 400 employees as of 2003, over half of the staff being field inspectors who only interfaced with the central office remotely.

MSA was largely overwrought with paper-intensive processes. This accounted for inefficient use of scare resources and longer wait times for MSA's constituents. There was a pent-up demand to link the Oracle-based organizational data warehouse to web-centric forms to enhance data collection and dissemination, as well as to link e-commerce capabilities to this system so that MSA fees could be collected and processed electronically. Given this additional functionality, the data warehouse could form the basis of a KM system with regard to agricultural and food-service-based information for the state. It could later be linked to a geographic informational system for mapping purposes (O'Looney, 2000).

While MSA was very interested in using IT to reduce the costs of doing business, it was largely an agency that historically had very little leadership in terms of technology. Prior to the summer of 2003, most of the technology was close to being considered obsolete. Most departmental programs within MSA had taken to crafting their own technology plans, often duplicating efforts of other programs or wasting resources, working around the IT department, which was considered a road block to success due to a lack of technical sophistication, organization, and good leadership. MSA's websites were the product of a largely inefficient IT staff. Prior to the arrival of the chief information officer (CIO), the agency had nothing more than a "brochure"-type website and had no plans to conduct any business using the Internet as its medium. These deficits were corrected with a reorganization of the IT department.

In the summer of 2003, the agency had just undergone a reorganization of the IT department, which effectively created the role of the CIO. The events leading to the reorganization and creation of the CIO position can be summarized as a chronic ineffectiveness to provide technical leadership to the agency. The reasons why this was the case can be considered, among other things, as the lack of a grounded operational plan that used IT to move the agency forward effectively. Some of the issues follow.

Actions:

- Knowledge hoarding

- Effort duplication

- Reluctance to seek new information from outside the organization

- Knowledge "cannibalism" (i.e., based on the above, staff would regurgitate information from within the organization taken as "gospel" with little acknowledgement that that information or knowledge could be antiquated)

Outcomes:

- Lengthy support times to customers

- Project overruns

- Incomplete projects

- Stagnate infrastructure/eroding infrastructure

- Mini-IT departments appearing within the agency outside of the IT department.

- Inefficient spending patterns; disorganized and ineffectual IT spending

In 2003, the agency hired its first CIO, who reported jointly to the Secretary of Agriculture and the Assistant Secretary of Agriculture. Additionally, this position is part of the senior leadership team, comprised of the aforementioned individuals, the senior counsel, and the public information officers. 
This team plans and responds to strategic issues (Barrett \& Greene, 2001). The CIO is also part of the program manager's team and the senior staff; these teams are composed of individuals that run the daily operations of each program within the agency.

\section{Business Model}

The traditional business model for the agency has been both the government-to-business and government-to-consumer models using "brick and mortar." Because the agency oversees the agriculture community, the natural constituency of this broad spectrum includes both the small farmer and larger meatpacking plants within the state, and everything in between. The agency conducts a number of programs for the agricultural community. Several programs are regulatory and compliant in nature and collect fees from either businesses or consumers. This model will be utilized through the transition to offering services electronically.

\section{Identification of the Industry}

MSA is a state government agency. As a departure from private sector firms, government agencies don't necessarily have competition (Blumstein, Cohen, \& Seth, 2007). In some case, these agencies adopt a monopolistic behavior, as each agency has a chosen arena in which to oversee using regulation, statutes, and procedures (Arthur \& Sheffrin, 2003). Most times, the lines of authority are drawn very clearly. No other agency, save perhaps a federal entity, can impose itself on the constituency of another agency. For example, a state's health department has no jurisdiction on collecting state taxes. From the standpoint of e-commerce, most or all state agencies have no worries about competition.

However, there are ancillary forces that, while not necessarily direct competition, may be considered impediments to the success of any state agency that wishes to have any e-strategy or e-commerce plan: special interest groups, lobbyists, and industry associations (Carroll \& Buchholtz, 2014). These forces are very strong, very organized, and can indirectly influence how an agency does business. It would also be a mistake not to mention the impact that a state legislature-and, indirectly, the public - can have on the methods that an agency utilizes.

\section{The Macroenvironment}

\section{Political-Legal Forces}

Force 1: There is increased pressure to regulate-in some cases, deregulate-but maintain authority and to maintain the quality of the agricultural services and systems for the citizens of the state. Examples include food safety statutes, livestock statues, agriculture environment statutes, dairy production statues, and weights and measures statutes.

Effect: As these laws are refined, passed, or repealed, there is usually an effort to reduce the amount of labor that it takes to serve these concerns. As such, opportunities are presented to modernize data collection and presentation efforts. Additionally, opportunities for streamlining programs that have fee income attached to them are the norm.

Force 2: There is increased pressure by third-party groups and the public-at-large to produce up-todate information in a timely manner.

Effect: These groups, some qualified as lobbying organizations, industry trade groups, and others, give a collective voice (in most cases) to individual citizens of the state. No one should underestimate these groups, as they have proven to be very powerful at introducing legislation that benefits their 
particular constituency. This legislation, while perhaps not directly impacting our chief concern within this case study, will force the agency to look at methods like e-commerce and e-services to minimize the reporting and collection requirements of MSA.

Force 3: The cyclical nature of political office means that high-profile projects may or may not have the blessing of the next administration or even the next legislative session due to other concerns or issues.

Effect: Usually, this blessing translates to a prioritization of projects along with funding. Should any of these efforts be deemed expendable or unfundable, or should priorities shift, it could spell the end of any long-term effort. From an implementation perspective, there is a special challenge to guard against this type of situation.

Force 4: Federal regulations or legislation could affect how a state agency conducts business.

Effect: Federal action of this caliber always has a rippling effect on state agencies, especially when such mandates are clearly accompanied by funding provisions.

\section{Economic Forces}

Force 1: At a time when general state fund dollars are being sought after, there is increasing pressures on state agencies to perform better with less (i.e., shrinking state and federal dollars for agency operations).

Effect: For the MSA, this translates into a renewed effort to use technology to automate manual processes and create cost savings. Typically, a downturn in state revenues tends to mean shrinkage in dollars available to an agency. Many times, this shrinkage also results in a smaller investment in technology. However, within MSA, the new administration has focused on improving agency output, and more funds have been made available as a technology investment.

\section{Technological Forces}

Force 1: One would think that the Internet's impact on consumer habits would be the Number 1 technological force behind MSA's effort to use e-commerce and e-services (Bass, 1986). However, that is false. Because MSA's main constituency are farmers, one has to look a bit deeper into the demographics of computer usage and ownership. A survey released in 2003 by the National Agricultural Statistics Service found that nearly half of U.S. farms have Internet access. A closer look at the Kansas statistics shows the following.

In 2002 , there were a projected 63,000 farms in Kansas.

- $62 \%$ said they had computer access.

- $59 \%$ said they owned or leased their computers.

However, this is where opportunity begins. Only

- $37 \%$ of these farms used the computers for farm-related business, and $48 \%$ had Internet access.

- $6 \%$ purchased agricultural inputs over the Internet.

- $5 \%$ conducted agricultural marketing activities over the Internet.

- $9 \%$ accessed government websites over the Internet (roughly 5,600 farms).

Effect: With so few of the farmers accessing the Internet for any type of e-commerce, marketing, or government access, there obviously isn't a pent-up demand for e-services. However, what this does 
show is that, as a government agency, MSA's populace is underserved on the Internet and has a tremendous opportunity for growth.

\section{Effect of the Internet on the Industry}

While the Internet has impacted all levels of the public sector, it has yet to have a sizable direct influence on MSA and state agricultural entities. Indirectly, the agency has self-imposed pressure on itself to use all the technology at its disposal to create efficiencies. In this regards, the Internet and related technologies are quickly becoming tools of choice for agencies like MSA.

As consumers, there has been a steady increase of Internet usage from every vantage: consumer purchasing, business information, analytics, etc. ("World Internet Users Statistics," n.d.). All of which use all the popular strategies: business-to-consumer, business-to-business, consumer-toconsumer, government-to-consumer, and government-to-business. It is not expected that this trend will reverse itself. Therefore, it is warranted that agencies provide more services electronically to meet the current and probable future needs of the population.

\section{Current Firm-Level Strategy}

The agency as a whole is currently using retrenchment strategies (purposeful budget or size reduction) to cope with the macroenvironment (Elmelund-Præstekær \& Klitgaard, 2012). Specifically, MSA is using turnaround techniques to find ways of dealing with the funding constraints put into place by the governor and legislators. In 2004, there was a mandate to cut agency budgets by $10 \%$. This cut came in the form of personnel reductions, program cutbacks, and some initiatives being cancelled. Despite, these actions, the retrenchment strategy produced opportunities for using technology.

\section{Current Business-Level Strategy}

MSA is using a mix of different business-level strategies to pursue lower operating costs and differentiation.

Commitment to Quality: A new program to monitor citizen complaints went online effective May 2004. This program provides feedback that is required to ensure that the main constituency of the agency has a voice that is monitored and reported automatically.

Process Innovations and Structural Innovations: The managers and directors of MSA meet once a year to conduct a strategic planning. Prior to this session, each program manager is tasked with evaluating how the agency could become more efficient and cut costs. Feedback received from this group contains ideas ranging from organizational restructuring, to implementation of technology based processes, to the elimination of ineffectual practices.

Many state agencies in the Midwest, along with cross functional interstate agency teams, are using the same approach to derive opportunities to achieve cost settings.

\section{Current Long-Term e-Commerce Strategy}

MSA did not have an e-strategy or e-commerce plan before the end of 2003. At the end of 2003, MSA embarked on a very ambitious process to create an e-business services delivery stratagem that encompasses information gathering and dissemination, education, marketing, and commerce.

MSA recognized that resources must continually be in place to cope with the constantly changing issues of the Internet and e-commerce. To meet this need, the following plan has been architected to craft, manage, and implement an e-strategy: 
1. Every week in the senior staff meeting, time is set aside to discuss the MSA e-strategy. Included in this discussion are e-commerce issues.

2. A dedicated intraprogram team composed of business users and technology personnel come together to discuss detailed e-strategy issues such as technology issues, implementation issues, technical support issues, or program-level adoption strategies.

3. Every other week, the CIO and the Communication Program staff meet to discuss Internet promotion and marketing strategies for the new website.

4. Once a month, the CIO participates in an intrastate meeting with other CIOs and top IT officials to discuss technology issues. At each of these meetings, time is taken to discuss e-commerce and eGovernment issues.

\section{Current Internet Marketing Strategy}

Currently, there is no concerted marketing strategy. As a state agency, very little effort is used to market the agency in the traditional sense. As the sole source in the state for the services that are provided, traditional marketing is a waste of taxpayer dollars. The same would hold true for any Internet marketing efforts. Current efforts by MSA to market itself on the Internet are references in traditional press releases to the existing MSA website as well as placing the URL on all publications (memos, business cards, etc.). However, the agency does market educational and instructional programs in a traditional sense.

It is obvious that with little or no effort being expended to market the current website, MSA has no real Internet community to speak of. This will have to change in order for any of the strategies suggested in this article to be successful. The new plan for Internet marketing will be as follows:

1. Make some information only available on the website.

2. Make some agency information available on the website first and then in traditional mediums.

3. Make sure all information that is in the public domain refers to the website.

4. Create value added services that are only available to the web.

5. Create interactive features to the website that will draw users and keep them coming back to the site.

6. Create e-subscription services that allow users to have new and updated content sent from the website.

7. Bring online more e-filing/e-fees services and phase out outmoded labor-intensive methods of handling processes.

\section{Current Firm Performance}

Because this is a public sector organization, one cannot use finance as the marker for firm performance. The true measure of a state agency lies in its ability to meet its stated mission as set out by the legislature. In this case, the challenge is to provide agricultural compliance, regulation and licenses.

\section{SWOT Analysis}

\section{Strengths}

Agency Leadership: The top management is composed of well-respected individuals who are considered leaders in their chosen fields of expertise. The Secretary of Agriculture and Assistant Secretary of Agriculture bring with them a wealth of expertise stemming from their agricultural roots. The senior staff (CIO, chief legal counsel, chief financial officer, and public information officer) all bring with them several years of experience within their chosen professions. Most of the senior staff has worked for the state and MSA for several years. The agency leadership as a whole is fully 
committed to using technology and, in specific, fostering the use of the Internet as a means of enhancing the services of MSA. Schellong (2007) advocates that both the presence and philosophy of senior leadership in IS/IT has a positive effect on organizational transformations that use technology as a tool for change.

Organizational Resources: MSA has a culture of letting the people who know call the shots. This type of delegation allows for the decentralization of most decisions. It also entails a certain amount of trust that employees at every level of the agency understand their roles and the roles of those around them. Additionally, the agency does a remarkable job of standardizing its approaches to purchasing, managing assets, quality control, etc. This shouldn't be surprising because more scrutiny is given to our public sector than our private sector (Rayner, 2003).

Physical Resources: Within the last several months, the leadership of the agency has made it an issue to address infrastructure items, such as lab-testing equipment, computers, and other types of physical assets. That notwithstanding, MSA has made it a priority to review the infrastructure needs of the agency on a regular basis. This is something that had seldom happened in the past.

\section{Weaknesses}

Personnel: While most of the employees at MSA are committed to MSA's mission, there are a number of employees, in key positions, who have been elevated to those positions through attrition, but who really do not have the skills to perform in their current positions. Because of the structure of state government, unless as employee performs an illegal act, it is very difficult, if not impossible, to replace that person. There are risks of not being able to terminate the person or, if so, not being able to refill that person because of budget constraints. There is also no human resources development plan in place for employees. This does little to encourage innovation. Additionally, despite the current economic climate of the country, most agencies cannot even hope to pay "market share" wages for their employees; consequently, the agency runs the risk of having to lower its expectations on incoming employees—or worse, risk flight from talented employees. Understanding the challenges associated with public sector staffing should be prioritized (Turkyilmaz, Akman, Ozkan, \& Pastuszak, 2011).

Budget: The trend seems to be that each year, agency budgets grow smaller and smaller due to the general decrease in overall state revenues as well as a shift in state priorities. Leedy and Ormrod (2005) noted that the budgeting cycle influences both the adoption and implementation cycles of technology in the public sector.

Program Management: MSA's parts seem to be lesser than the whole. For far too long, programs have operated in isolation from each other. Additionally, most programs have been slow to realize the benefits of using the current technology available at MSA.

\section{Opportunities}

Federal/State Legislation: Depending on the exact nature of the legislation, opportunities can be created. The United States Department of Agriculture (USDA) mandate for animal disease traceability is a good example of how the agency can use that mandate to further push its offerings on the Internet (USDA, 2015).

Private Industry Consolidation: As the agricultural community goes through consolidation, there's an opportunity for MSA to provide leadership through the use of enhanced services (USDA, 2014). Interstate Coalitions/Projects and Intrastate Agency/Organization Projects: These projects are easily the way that MSA will have opportunities for growth. By combining resources for a regional effort, the agency will reap the rewards and lower any of the associated risks. 


\section{Threats}

Federal/State legislation: Legislation/regulation is both an opportunity and a threat. Obviously, laws that can create opportunities are also laws that can create threatening conditions under which already underallocated initiatives can be further burdened (Organic Consumers, n.d.).

Budget Reductions: The historical trend has been decreased funding for everyday operational activities. Even though IT initiatives can be viewed as investments as opposed to expense allocations, there still remains the issue of initial funding (Johnson, Oliff, \& Williams, 2011).

Unforeseen Circumstances: Unforeseen threats such as the Midwest flood of 2008 threaten the operational agenda of the agency, as such events impose an undue strain on agency resources (Xiao, Wan, \& Hewings, 2013). See Figure 6.

\begin{tabular}{|c|c|c|}
\hline & $\begin{array}{l}\quad \text { Opportunities } \\
\text { - Federal/State Legislation } \\
\text { - Private Industry } \\
\text { Consolidation } \\
\text { - Inter-State/Intra-agency } \\
\text { Projects }\end{array}$ & $\begin{array}{l}\text { Threats } \\
\text { - } \text { Federal/State Legislation } \\
\text { - Budget Reductions } \\
\text { - Unforeseen Circumstances }\end{array}$ \\
\hline $\begin{array}{ll} & \text { Strengths } \\
\text { - } & \text { Agency Leadership } \\
\text { - } & \text { Organizational Resources } \\
\text { - } & \text { Physical Resources } \\
& \text { Weaknesses } \\
\text { - } & \text { Personnel } \\
\text { - } & \text { Budget } \\
\text { - } & \text { Program Management }\end{array}$ & \multicolumn{2}{|c|}{$\begin{array}{l}\text { Alternative 1: Short Term IT Projects } \\
\text { Alternative 2: Knowledge Management Techniques } \\
\text { Alternative 3: Cooperative Projects with outside entities } \\
\text { Alternative 4: e-Services That Speed Fee Collections and Data } \\
\text { Acquisition }\end{array}$} \\
\hline
\end{tabular}

Figure 6: SWOT Analysis 


\section{SWOT Matrix}

Alternative 1: MSA should endeavor to sponsor internal projects that are tightly focused and have short durations. These types of projects have less of a chance of being changed to due to changes that occur as a result of administration turnover or changes in the legislative will of the state from one legislation session to the next. Currently, most of the e-services platform for MSA is being implemented in this fashion.

Alternative 2: Because information and knowledge has to be shared, the agency should undertake some practical KM techniques to ensure that the overall competency of the agency does not diminish over time. For all of the e-services projects, MSA has instituted knowledge repositories for all meetings, project matter, and reviews.

Alternative 3: Because resource scarcity is an issue, MSA should explore opportunities to cooperatively sponsor projects that will allow the agency to further its mission and minimize the impact that such a pursuit would have on the internal resources of MSA.

Alternative 4: The agency should pursue e-commerce and related activities that will allow constituencies of the agency to use self-service facilities. By doing so, the agency will free up personnel to take up other matters of importance and lower the total cost of providing these services electronically.

\section{Analysis of the Alternatives}

These alternatives have some similarities in both their positive and negative attributes. However, each should be analyzed on its own without regard to the other congruent alternative.

\section{Alternative 1: Short-Term IT Projects}

The pros of Alternative 1 include the following: (a) Tightly focused projects make sense due to the cyclical nature of the government year. Having such tightly focused projects will allow an agency to show progress in smaller reporting periods. (b) The agency can eliminate "project creep" by having discrete projects. (c) Smaller projects usually tend to have lower costs, which are more easily funded.

The cons of Alternative 1 include the following: (a) Smaller projects may not be able to meet strategic needs. (b) Not all projects are easily collapsible into smaller projects. (c) Not being able to fund the entirety of the master project could leave the project as a whole at risk, because present funding of the smaller, mini-projects does not guarantee that projects that come later will be funded.

\section{Alternative 2: KM Techniques}

The pros of Alternative 2 include the following: (a) KM techniques lessen entrenchment of employees. (b) They also allow more innovation with easier access to information.

The cons of Alternative 2 include the following: (a) Implementing KM requires a cultural change of the organization. (b) KM techniques can be timely to implement. (c) They can be costly to implement. (d) There is no guarantee of results.

\section{Alternative \#3: Cooperative Projects With Outside Entities}

The pros of Alternative 3 include the following: (a) There is a lower total cost of ownership. (b) There is a lower risk of project failure. (c) There is a lower impact to internal resources. (d) There are faster implementation times. 
The cons of Alternative 3 include the following: (a) The parties involved may have to compromise on solution. (b) There is less control on how the work is performed and what standards to use. (c) Payment schedules may be in conflict to cash flow projections. (d) There may be ownership issues unless the roles are clearly defined.

\section{Alternative \#4: e-Services That Speed Fee Collections and Data Acquisitions}

The pros of Alternative 4 include the following: (a) These e-Services lower labor costs when implemented. (b) They ease budget issues for programs that rely on fee collection to operate. (c) There is a faster compilation of management reports.

The cons of Alternative 4 include the following: (a) The e-Services may have high implementation costs. (b) Several business processes may need to be reworked. (c) Legislative changes may be needed to move forward. (d) The e-Services may be timely to implement.

\section{Recommended Alternatives}

In MSA's case, Alternatives 3 and 4 are being pursued at this time. Because of MSA's resource mix, it is highly desirable to minimize both the implementation costs as well as the long-term ownership costs.

In the case of Alternative 3, it is desirable to enter into projects that add both tactical and strategic values to the agency. By entering into these cooperative projects with outside entities, the agency can speed to market initiatives that would otherwise take an undetermined amount of time to implement.

In the case of Alternative 4, MSA wishes to reduces the labor costs associated with providing compliance and licensing services to the agricultural community. With a healthy promotion campaign and the right technical solution, the agency projects a rapid adoption of these services by the larger entities that do business with the agency first, with the smaller entities following on later.

\section{Implementation}

Over several months, MSA slowly assembled a long-term e-commerce implementation plan, which consisted of the following steps:

1. Use a third-party vendor to establish e-commerce presence. MSA has selected a third-party vendor to collect fees for one program (Pesticide/Fertilizer) as a pilot project. MSA chose the vendor based on the vendor's experience with other state agencies with similar programs around the country. Additionally, by doing this in a limited fashion, it allows the agency to further extend its online presence without extending its costs. Under a somewhat unique agreement with the vendor, the vendor will not charge the agency for its service but instead pass any costs to the business using the online service by way of a processing fee.

2. Work with legislators to change existing statutes so that collecting more fees online is permissible. Currently, most fees that MSA collects has to be accompanied by some sort of notarized documentation at the point of payment. With these types of restriction, the agency is not able to move forward with converting more fee collections to an e-filing system.

3. Rebrand and redesign the current agency website. The current website has not changed much since its inception several years ago. By comparison, sister agencies such as the Department of Revenue have gone through several revisions. The new website will offer ecommerce options for e-filing (when allowed by law), as well as serving as a portal for anyone looking for information about agriculture and agricultural commerce within the state. 
4. Work with the state to change the electronic receipting of funds. At the time, the agency is only able to take utilize Discover cards for credit card payments due to the current processing fee structure that is in place. These contracts, on a state level, are renegotiated each year. Upon lowering these fees, MSA will see a dramatic rise in credit card usage overall, but will allow more flexibility with e-commerce issues.

5. Develop an end-to-end system of e-filling, e-fee collection, and receipting. As mentioned previously, most programs have some sort of filing requirements and document creation (i.e., license card, license placard, receipt, etc.) as part of the process. To create a one-stop ecommerce version, the agency has to account for all these facets long term. In the short term, this will be quasiautomatic with some of the steps being handled manually. For example, in the case of the Pesticide/Fertilizer program, fees will be collected electronically through the third-party vendor for processing. The citizen will then send the mandatory documentation through email, along with the electronic receipt number given to them. In the future, this MSA will eliminate this second step by having the documentation filed electronically once the statute surrounding these fees has been updated to reflect electronic means of transmission.

6. Encourage the usage of the new portal. By lowering the optional processing fees associated with some programmatic fees along with a strong marketing strategy, MSA can drive traffic and subsequent usage to the website. MSA will also seek to create alliances with sister agencies to create more inbound traffic, thus generating more purchasing opportunities.

\section{Control}

The e-services project has several goals to meet to be considered successful.

1. After the first year of offering, the agency would like to see a $10 \%$ reduction in paper filing in each of the first 3 years of e-filling/e-fee collection service.

2. The agency would like to see a transition from fees collected by check to other electronic means move from $5 \%$ to $35 \%$ in the first year after it is possible to accept other credit card payments other than Discover Card.

3. The project will have paid for itself after 4 years by reducing the overall workload of the current staff that supports licensing and compliance reporting for the agency.

To control these issues, the agency will rely on the state-implemented project methodology to manage and monitor the project(s) as they are implemented. Weekly and, in some cases, biweekly status meetings are being held with various constituents with MSA to ensure careful coordination and implementation.

These goals have been carefully considered and are a result of past internal studies and legislative post audits that suggest that implementing such measure should produce similar cost savings for the agency.

\section{Conclusion}

Resource issues aside, MSA has a bright future serving the citizens of the state. The leadership has set out an agenda of using technology to accomplish the challenging mission of the agency and is taking unheralded steps to ensure success. The recommendations presented in this text are different than the recent direction of the agency because none of these items were seriously considered. Having an e-Services strategy was a blue-sky item and utilizing e-commerce was stuff from which dreams were made. Now, against the backdrop of e-services, the agency will start to use KM as a strategic tool, with the outcome leading to improved quality in the services that they are able deliver. 
As these items are implemented, the agency will see steady increases in cost savings. However, the agency should be careful not to overestimate the savings it should expect. Without the proper education and marketing, even the best e-Services will go unutilized.

Also, the agency must be forever vigilant that success today by no means ensures success tomorrow. In other words, MSA cannot rest; it will continually have to examine these systems and identify opportunities for growth.

\section{References}

Ajzen, I., \& Fishbein, M. (1980). Understanding attitudes and predicting social behaviour. Eaglewood Cliffs, NJ: Prentice-Hall.

Arthur, O., \& Sheffrin, S. M. (2003). Prentice Hall economics: Principles in action. Boston, MA: Pearson Education, Inc.

Bagozzi, R. P., Davis, F. D., \& Warshaw, P. R. (1992). Development and test of a theory of technological learning and usage. Human Relations, 45, 660-686.

Baker, P. M., Hanson, J., \& Myhill, W. N. (2009). The promise of municipal WiFi and failed policies of inclusion: The disability divide. Information Polity, 14, 47-59.

Barrett, K., \& Greene, R. (2001). Powering up: How public managers can take control of information technology. Washington, DC: CQ Press.

Bass, F. M. (1986). The adoption of a marketing model: Comments and observations. In V. Mahajan $\&$ Y. Wind (Eds.), Innovation diffusion models of new product acceptance (pp. 27-36). Cambridge, MA: Ballinger.

Becker, S. A. (2005). E-government usability for older adults. Communications of the ACM, 48, 102-104.

Blumstein, J. F., Cohen, M. A., \& Seth, S. (2007). Do government agencies respond to market pressures? Evidence from private prisons. Vanderbilt Law and Economics Research Paper (03-16), 03-05.

Bowman, A. O. M., \& Kearney, R. C. (2012). State and local government. Cengage Learning.

Budd, R. J. (1987). Response bias and the theory of reasoned action. Social Cognition, 5, 95-107.

Carroll, A., \& Buchholtz, A. (2014). Business and society: Ethics, sustainability, and stakeholder management. Stamford, CT: Cengage Learning.

Chhabra, S. (Ed.). (2009). Integrating e-business models for government solutions: Citizen-centric service oriented methodologies and processes. London, UK: IGI Global.

Davis, F. D. (1989). Perceived usefulness, perceived ease of use, and user acceptance of information technology. MIS Quarterly, 13, 319-340.

Davis, F. D., Bagozzi, R. P., \& Warshaw, P. R. (1989). User acceptance of computer technology: A comparison of two theoretical models. Management Science, 35, 982-1003.

DeLone, W. H., \& McLean, E. R. (1992). Information systems success: The quest for the dependent variable. Information Systems Research, 3, 60-95.

DeLone, W. H., \& McLean, E. R. (2002, January). Information systems success revisited. In Proceedings of the 35th Annual Hawaii International Conference on System Sciences (pp. 2966-2976). Big Island, HI: IEEE. 
Dishaw, M. T. and Strong, D. M. (1998a). Assessing software maintenance tool utilization using task-technology fit and fitness-for-use models. Journal of Software Maintenance: Research and Practice, 10, 151-179.

Dishaw, M. T. and Strong, D. M. (1998b). Supporting software maintenance with software engineering tools: A computed task-technology fit analysis. Journal of Systems and Software, 44, 107-120.

Elmelund-Præstekær, C., \& Klitgaard, M. B. (2012). Policy or institution? The political choice of retrenchment strategy. Journal of European Public Policy, 19, 1089-1107.

Fountain, J. (2001). Building the virtual state. Washington, DC: Brookings Institution Press

Goodhue, D. L. (1995). Understanding user evaluations of information systems. Management Science, 41, 1827-1844.

Goodhue, D. L., \& Thompson, R. L. (1995). Task-technology fit and individual performance. MIS Quarterly, 19, 213-236.

Heeks, R. (2008). eGovernment for development. Retrieved from http://www.egov4dev.org/success/definitions.shtml

Hurley, T. A., \& Green, C. W. (2005). Knowledge management and the nonprofit industry: A within and between approach. Journal of Knowledge Management Practice, 6, 1-10.

Jaeger, P. T. (2004a). Beyond Section 508: The spectrum of legal requirements for accessible egovernment web sites in the United States. Journal of Government Information, 30, 518-533.

Jaeger, P. T. (2004b). The social impact of an accessible e-democracy disability rights laws in the development of the federal e-government. Journal of Disability Policy Studies, 15, 19-26.

Janssen, D., Rotthier, S., \& Snijkers, K. (2004). If you measure it they will score: An assessment of international eGovernment benchmarking. Information Polity, 9, 121-130.

Johnson, N., Oliff, P., \& Williams, E. (2011, February 9). An update on state budget cuts. Retrieved from Center on Budget and Policy Priorities: http://www.cbpp.org/sites/default/files/atoms/files/3-13-08sfp.pdf

Keil, M., Beranek, P. M., \& Konsynski, B. R. (1995). Usefulness and ease of use: Field study evidence regarding task considerations. Decision Support Systems, 13, 75-91.

Kunstelj, M., \& Vintar, M. (2004). Evaluating the progress of e-government development: A critical analysis. Information Polity, 9, 131-148.

Leavitt, H. J. (1965). Applied organizational change in industry: Structural, technological and humanistic approaches. In J. March (Ed.), Handbook of organizations (pp. 1144-1170). Chicago, IL: Rand-McNally.Leedy, P. D., \& Ormrod, J. E. (2005). Practical research: Planning and design (8th ed.). Upper Saddle River, NJ: Prentice Hall.

National Agriculture Statistics Service. (n.d.). USDA's National Agricultural Statistics Service Kansas Field Office. Retrieved March 8, 2015, from http://www.nass.usda.gov/Statistics_by_State/Kansas/index.php

O'Looney, J. (2000). Local government on-line. Washington, DC: ICMA Management Association.

Organic Consumers. (n.d.). The truth about the National Animal Identification System (NAIS). Retrieved from https://www.organicconsumers.org/news/truth-about-national-animalidentification-system-nais 
Qureshi, S. (2005). E-government and IT policy: Choices for government outreach and policy making. Information Technology for Development, 11, 101-103.

Rayner, S. (2003). Democracy in the age of assessment: Reflections on the roles of expertise and democracy in public-sector decision making. Science and public policy, 30, 163-181.

Schellong, A. (2007). Extending the technology enactment framework. Program on Network Governance (Working Paper PNG07-003). Retrieved from http://www.ksg.harvard.edu/netgov/files/png_workingpaper_series/PNG07003_WorkingPaper_extending_technology_enactment_framework_schellong.pdf

Smith, A. (2010). Government online: The Internet gives citizens new paths to government services and information. Retrieved from http://www.pewinternet.org/files/oldmedia//Files/Reports/2010/PIP_Government_Online_2010_with_topline.pdf

Stewart, T. (1986). Task fit, ease-of-use and computer facilities. In N. Bjørn-Anderson, K. Eason, \& D. Robey (Eds.), Managing computer impact: An international study of management and organizations (pp. 63-76). Norwood, NJ: Ablex.

Swartz, N. (2004). E-gov slowly gaining acceptance, but must mature. Information Management Journal, 38, 16.

Turkyilmaz, A., Akman, G., Ozkan, C., \& Pastuszak, Z. (2011). Empirical study of public sector employee loyalty and satisfaction. Industrial Management \& Data Systems, 111, 675-696.

U.S. Department of Agriculture (USDA). (2014). Amber waves. Retrieved from http://www.ers.usda.gov/amber-waves/2004-february/have-seed-industry-changes-affectedresearch-effort.aspx\#.VehVJflVhBc

U.S. Department of Agriculture (USDA). (2015). Animal and plant health inspection service. Retrieved from http://www.aphis.usda.gov/wps/portal/aphis/ourfocus/animalhealth?1dmy\&urile=wcm\%3apat h\%3a\%2FAPHIS_Content_Library\%2FSA_Our_Focus\%2FSA_Animal_Health\%2FSA_Tracea bility

Venkatesh, V., \& Davis, F. D. (1996). A model of the antecedents of perceived ease of use: Development and test. Decision Sciences, 27, 451-481.

Ward, A., Baker, P. M., \& Moon, N. W. (2009). Ensuring the enfranchisement of people with disabilities. Journal of Disability Policy Studies, 20, 79-92.

World Internet Users Statistics and 2015 World Population Stats. (n.d.). Retrieved April 8, 2015, from http://www.internetworldstats.com/stats.htm

Xiao, Y., Wan, J., \& Hewings, G. J. (2013). Flooding and the Midwest economy: Assessing the Midwest floods of 1993 and 2008. GeoJournal, 78, 245-258.

The International Journal of Applied Management and Technology (IJAMT), sponsored by Walden University's School of Management, is a peer-reviewed, online journal that addresses contemporary national and international issues related to management and technology. The objectives of the IJAMT are to: (a) encourage collaborative and multi-disciplinary examinations of important issues in business and technology management, and (B) engage scholars and scholar-practitioners in a dynamic and important dialogue.

Walden University Publishing: http://www.publishing.waldenu.edu 